\title{
The Effect of Blended Learning on Learning Activities and Student Learning Outcomes in Basic Trimming Subjects at SMKN 8 Surabaya
}

\author{
Fitria Hansyah Fatmasari
}

\author{
Universitas PGRI Adi Buana ${ }^{l}$, \\ *Corresponding author.E-mail: fitria_hansyah@yahoo.co.id
}

\begin{abstract}
The process of learning practice felt very less. Practices that exist in learning using mannequinand using the model. One of creation in learning practice is blended learning. Learning process that combines face- to-face learning with online learning. Learning activities for students of SMKN 8 Surabaya who use blended learning significantly higher 88.96 . Thus, the model of learning blended learning into learning innovation that can improve learning outcomes in students SMKN 8 Surabaya.
\end{abstract}

Keywords: blended learning, learning activities, learning outcomes

\section{INTRODUCTION}

The Indonesian law No.20 of 2003 on the National Education System (Sisdiknas), stated that with distance education is "education that learners separate from educators and learning using various sources of learning through communication technology, information and other media. This means that science and technology and development require people to make changes so as to adjust the times. The role of science and technology is very important for every individual who wants to improve his/her ability to follow the competitive competition.

Education is believed to be a strategic tool to improve people's lives. Humans become intelligent through education, having the ability or skill, a good attitude of life, so they can get along well in the community. According to Engkoswara, et al. (2010: 1) that education becomes an investment that gives social and personal benefits that make the nation and individually dignified into a degree of humanity. Utilization also can provide new insights and learning innovations for students to be able to do learning activities independently.

The Activity of learning activities of students can be seen from students' learning outcomes. The ability of students is shown by the high and low learning outcomes.

According to the Supratiknya in Widodo, et al. (2013: 34)

suggests that the results of learning that became the object of class assessment in the form of new abilities obtained by students after following the learning process about certain competencies. Acquisition of student learning outcomes can be seen in the merger between direct learning and through the utilization of information technology can be used as a learning to make learning activities and student learning outcomes increased, one of the learning process is blended learning.

Singh (2003) states that blended learning allows students to engage in learning outside the confines of the classroom with synchronous tools, such as web conferencing, Skype and group chats, and asynchronous tools that include discussion boards. This learning can be used outside of the classroom, giving students the opportunity to be able to interact directly with the teacher as long as the given access is used.

SMK Negeri 8 Surabaya more emphasize theory and practice. Practice that is in learning by using menekin and model. In the meantime, practice can only be done using menekin. Blended learning is expected to cut face-to-face meetings in the classroom with the delivery of materials and practice. In basic hair pruning subjects that use blended learning can improve student learning activities and can affect student learning outcomes ranging from the realm of knowledge, attitude and skills. 


\section{METHODS}

The design used in this research is pre-test post-test control group design. This design consists of two groups: the experimental group and the control group. Image of Research Flow;

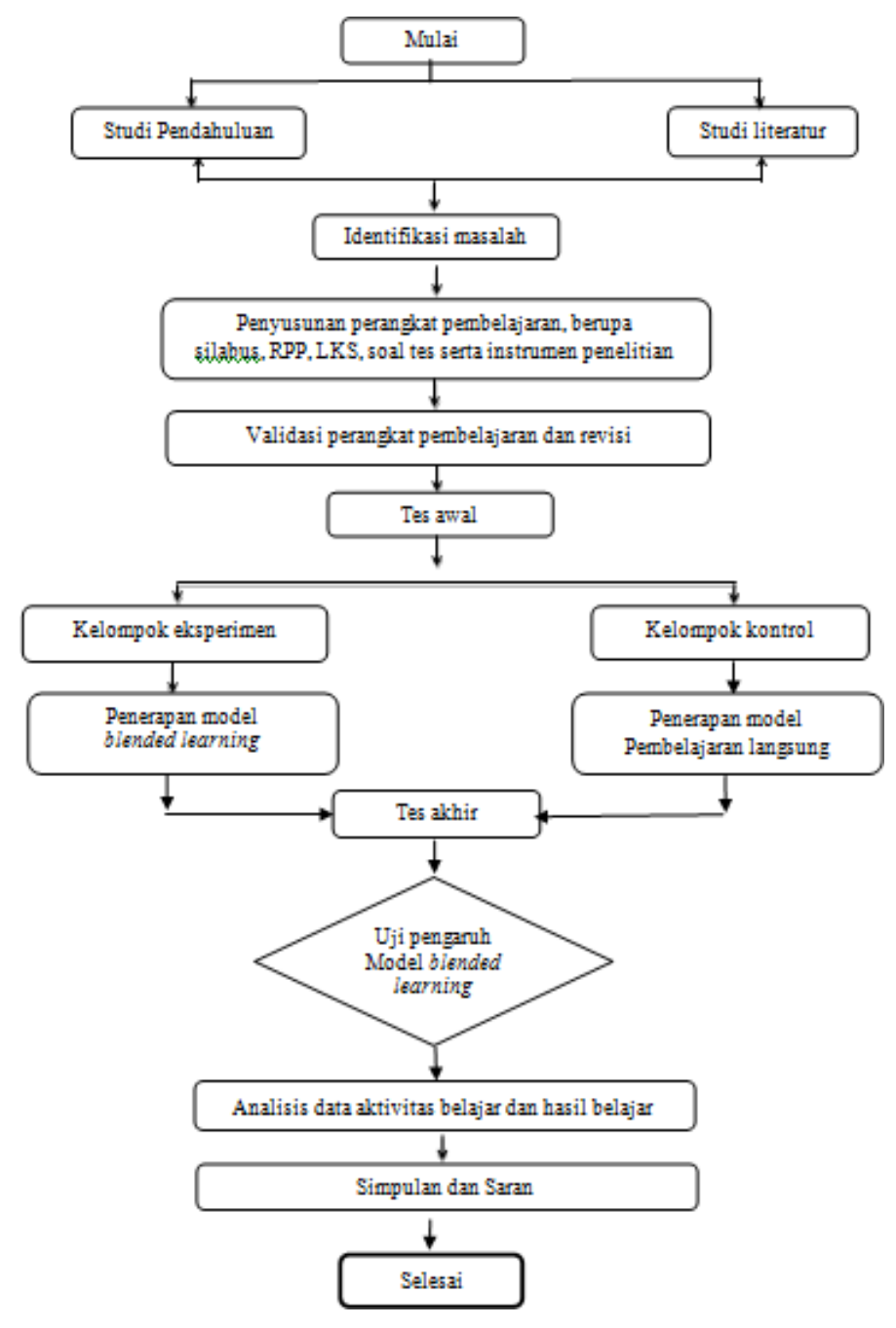

Figure 1. Research Flow

According Arikunto (2006: 151) research instrument is a tool or facility used by researchers in collecting data so that the job easier and the results better, in a more accurate, complete, and systematic so that more easily processed. Data collection techniques for learning outcomes in the field of attitude and learning outcomes in the realm of skills used in this study by observation, used to collect data on student learning activities, attitude and skills learning outcomes. Observers do the assessment by observing the students during the learning process which takes place in the classroom. Test techniques are used to derive cognitive domain learning outcomes. The test of learning outcomes done in the experimental class and control class is obtained through pre-test and post-test result. The test is given after the pruning of basic hair pruning material is given, then the researcher gives the problem related to the topic to the student through media information/ internet (web online). The purpose of this question is to know the mastery of the material taught, and to determine the learning outcomes achieved by the students. Before the instrument can be used, it is necessary to test the validity and reliability so that the instrument to be used really valid. Analytical technique used to test the hypothesis in this study using t-test that is comparing two variables.

\section{RESULTS}

Data of Experiment Class Result with Blended Learning

The data of students' learning result of experimental class using blended learning model consist of: (1) learning activity (2) learning result of knowledge, (3) attitude learning result and (4) result of learning skill. 
student skill aspect used observation of performance test at student, while learning activity obtained through observation and assessment during learning progress.
Knowing the learning result of student's knowledge field using post-test problem, to know the learning result of student attitude aspect used attitude observation, whereas to know the result of learning of

\section{(1) learning activities}

Table1: Learning Activities

\begin{tabular}{|c|c|c|c|c|}
\hline \multicolumn{4}{|c|}{$\begin{array}{c}\text { Average score learning outcomes sphere learning } \\
\text { activities class learning model blended learning } \\
\text { Meeting- }\end{array}$} & \multirow[t]{2}{*}{$\begin{array}{c}\text { Skor Rata- } \\
\text { Rata } 4 \\
\text { pertemuan }\end{array}$} \\
\hline 1 & 2 & 3 & 4 & \\
\hline 89,27 & 89,51 & 88,80 & 88,27 & 88,96 \\
\hline \multicolumn{2}{|c|}{ Lowest Score is } & & & \\
\hline
\end{tabular}

Based on the average score of student learning activity on the table shows the lowest score of the students equal to 86 while the highest score of 92.66 .

\section{(2) knowledge learning outcomes}

Table 2. Learning Outcomes Knowledge

\begin{tabular}{ccccc}
\hline Test type & $\begin{array}{c}\text { Lowest } \\
\text { score }\end{array}$ & & $\begin{array}{c}\text { Skor_ } \\
\text { Tertinggi }\end{array}$ & $\begin{array}{c}\text { Skor Rata- } \\
\text { Rata }\end{array}$ \\
\cline { 2 - 2 } Pretest & 67 & & 87 & \\
Posttest & $\underline{87.00}$ & & $\underline{100}$ & \\
\hline
\end{tabular}

Score of learning result students of experimental class, student with blended learning model which shown in table shows that knowledge learning result with lowest score on pre-test is 67.00 and highest score at 87.00 with average score from pre-test equal to 76.43 . In the post-test results obtained the lowest score of 87 while the highest score of 100 with an average score of 95.3.

\section{(3) learning result of attitude aspect}

Table 3. Outcome Learning Attitudes

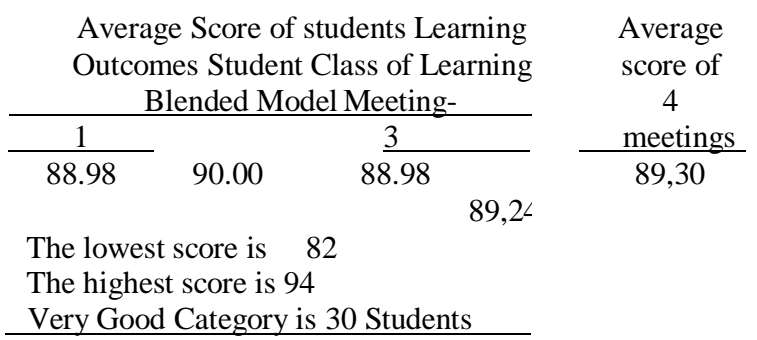

The first meeting, the mean score of learning achievement of students' attitude aspect was 88.98, then at the second meeting increases with average score of 90.00 , at third meeting decreased again with average score equal to 88.98 and fourth meeting again decrease with average score at a rate of 89.24 , so the average score for the learning outcomes of the students' attitudes from the four meetings was 89.30. Based on the average score of learning outcomes in the students attitude in the table shows the lowest score achieved by students is 82 , while the score of learning achievement of the highest student attitude is 94 . 


\section{(4) The skill area learning outcomes}

Table 4. Skills Learning Outcomes

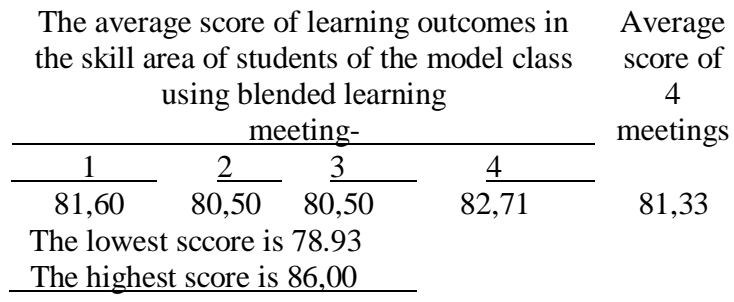

The first meeting, the average score of the students' learning achievement level of 81.60, then in the second meeting increased by an average score of 80.50 , at the third meeting with an average score of 80.50 , at the fourth meeting increased of 82.71. The average score of students' learning skill from all four meetings was 81.33. The scores for the learning activities have increased and decreased from the first meeting to the fourth meeting. At the first meeting, the average score of student learning activity was 76.07, then in the second meeting increased by an average score is 77.11 then in the third meeting decreased by 76.96 and at the fourth meeting decreased with the average score is 71.02. The average score of student learning activity from all four meetings was 75.28. Meanwhile, on the score of learning outcomes in the field of knowledge of control class students with direct learning model showed the lowest score on pretest is 37.5 , while the highest score is 72.5 , and the average score of post-test control class direct learning model the lowest score is 47.5 with the highest one is 67.5. In the learning outcomes, the attitude of students has improved from the first meeting to the fourth meeting. At the first meeting, the average score of students' learning achievement aspect was 60.40, then at the second meeting increased by an average score of 74.40 and in the third meeting increased again with an average score of 76.60 and The fourth encountered an increase of 90.13 , so the average score for the learning outcomes of the students' attitudes of the four meetings was 75.33. Based on the average score of learning outcomes, the attitude of students who showed the lowest score was 71.66, while the highest score was 78.00. Students' skill learning outcomes are known to use observation of performance tests conducted during the learning activities take place. The average score of learning outcomes of students' skill areas increased from the first meeting to the fourth meeting. At the first meeting, the average score of the students' learning achievement score of 69.09 , then in the second meeting increased by an average score of 74.96 , then in the third meeting increased with an average score of 80.50 and at the fourth meeting with an average score of 81.17. The average score of students' learning skill learning outcomes from all four meetings was 76.43. Based on the average score of skills learning result shows the lowest score of students is 74.63, while the highest score is 79.98. In order to know the truth of this research, hypothesis testing on the value of learning activity, knowledge learning outcomes, attitude learning achievement, and skill learning result using independent sample $\mathrm{t}$ test. Testing data of learning result of knowledge is done by using independent sample t-test in a row. In the hypothesis test of learning activity is known the value thitung adalah 29.203 value thitung This is compared to the t-table value sought in the $\mathrm{t}$ distribution table. $\mathrm{T}$ distribution tables are determined by degrees of freedom $(\mathrm{df})=58-2=56$. From this calculation obtained ttabel as 1.67. Then it is obtained a significant value on the line of equal variances assumed the test value of Fhitung $=0,541$ and significant value $0,000<0,01$ so that $\mathrm{H} 0$ is rejected and $\mathrm{H} 1$ is accepted. Thus, based on the description can be concluded that students learning activities on students who are with blended learning, significantly higher compared with students who only get direct learning. The result of the hypothesis test of knowledge domain known thitung value is 30.680 . This thitung is compared to the ttabel value sought in $t$ distribution table. The distribution table $\mathrm{t}$ is determined with degrees of freedom $(\mathrm{df})=58-2=56$. From this calculation obtained ttabel value of 1.67. Thus, a significant value in the line of equal variances assumed test value Fhitung $=22.266$ and significant value 0.000 $<0.01$ then Ho is rejected and H1 is accepted. Thus it can be concluded that the result of learning of knowledge in students who with blended learning, significantly higher than the students who only get direct learning. The result of the hypothesis test of learning achievement is known as thitung value is 25,523 . This thitung is compared to the ttabel value sought in $\mathrm{t}$ distribution table. $\mathrm{T}$ distribution table is determined with degrees of freedom $(\mathrm{df})=58-2=56$. From this calculation obtained ttabel value of 1.67. Thus, a significant value in the line of equal variances assumed the test value Fhitung $=2,129$ and significant value $0,000<0.01$ then $\mathrm{Ho}$ is rejected and $\mathrm{H} 1$ is accepted. Thus, it can be concluded that the results of learning attitudes on students with blended learning, significantly higher than students who only get direct learning. The result of the hypothesis test of learning skill domain known as thitung value is 13,923 . This 
between students and teachers, student attitudes toward this method, student-centered learning. Blended learning strategies can save the time for teachers and students.

Mugenyi, et al (2017) in his study "blended learning effectiveness: the relationship between student characteristics, design features and outcomes". The study found the effectiveness of learning with blended learning given to 238 respondents to collect data on the characteristics or background of students which measure the learning outcomes on performance. The availability of intrinsic motivational data and other independent development instruments. This also corresponds to Zaytoon's theoretical study (in Nwoke et al, 2014: 38) states the blended learning model as a kind of electronic learning that is a substitute for traditional learning, since blended learning involves electronic learning tools including computers, Internet, lectures, and training that are in the classroom such as computer labs and sophisticated classes. From the research results obtained and the results of the discussions described above, it is advisable to use blended learning for teaching and learning process that can be done in the classroom and outside the classroom, this learning makes easier for students to find references or material given by the teacher, and in doing task. The implication in this research is that the improvement of attitude learning achievement in the subject of basic hair pruning can be done by applying blended learning. The research results of Poon (2013) on learning outcomes of skills domian reveal that blended learning: an institutional approach for enhancing students' learning experiences. Blended learning, usually seen as a combination of face-to-face and online learning methods, can influence students' perceptions of the learning environment, learning experience, learning outcomes, and academic achievement. However results of Khader's (2016) entitled The Effectiveness of Blended Learing in Improving Students' Achievement in Third grade Science in Bani Nana. The results of his research have found that statistically there is a difference in learning achievement that is influenced by the experimental learning group. The results of supporting research and the results of the discussions described above, it is recommended to use blended learning for teaching and learning process that can be done in the classroom and outside the classroom, this learning makes it easier for students to find references or material given by teachers, and in doing task. The implication in this research is that improvement of skill learning result in basic hair pruning subject can be done by applying blended learning.

\section{CONCLUSION}

Humans are a very important resource for nation and 
improving the learning outcomes of the skill areas on basic hair pruning subjects can be done by applying blended learning. qualified human resources that are intelligent and having good characters. Education is a vehicle for creating a human resource characteristic. The role of education to improve individual performance and insight. Educational problems can not be separated from the school institutions to explore all the abilities possessed by students in accordance with the talents and interests to follow the development of science and technology. Technology provided to students by utilizing internet facilities which can be used in distance learning online. Utilization of technology is required in the process of teaching and learning in the classroom. The role as a substitute for the activities of teaching and learning activities are usually done by teachers in the classroom set in the form of online web. In addition, this can be used if the teacher is unable to attend the class. Utilization can also provide new insights and learning innovations for students to be able to learn independently. The result of learning of knowledge domain for the students who learn to use blended learning is significantly higher than those who learn to use direct instructional media. The result of learning of knowledge domain for the students who learn to use blended learning can improve the result of learning knowledge for the students during the learning process, because the learning process using blended learning includes the activity that will be done by the students during the learning process. The implication of this study is that the improvement of knowledge learning outcomes in basic hair pruning can be done by applying blended learning. The learning outcomes of students' attitude domain for the students who learn to use blended learning is significantly higher than those who learn with the direct learning. The result of learning of attitude aspect for students who learn to use blended learning can improve the learning achievement aspect for students during the learning process, because the learning process using blended learning includes honesty, discipline, responsibility, and confidence. The implications of this study are that improving learning outcomes in the field of basic hair pruning can be done by applying blended learning. The learning outcomes on skill domain for students who learn with blended learning are significantly higher than those who use direct learning. Skill learning outcomes for students who learn using blended learning can improve learning outcomes for students during the learning process, because the learning process using blended learning includes activities that will be done by students gradually until students are proficient in doing basic pruning. The implications of this study are that

\section{REFERENCES}

[1] Almasaeid, T.F. (2014). The effect of using blended learning strategy on achievementand attitudes in teaching science among $9^{\text {th }}$ grade students. European Scientific Journal, 10(31), 133-145.

[2] Arikunto, S. (2006). Prosedur penelitian suatu pendekatan praktik. Jakarta: Rineka Cipta. Budiharti, R., et al. (2015). Penggunaan blended learning dengan media moodle untuk meningkatkan kemampuan kognitif siswa SMP. Cakrawala Pendidikan, 1, 140-148.

[3] Engkoswara \& Komariah, A. (2010). Administrasi pendidikan. Bandung: Alfabeta.

[4] Jeffrey, L. M., Milne, J., \& Suddaby, G. (2014). Blended learing: How teachers balance the blend of online and classroom components. Journal of information teachnology education: Research, 13, 121-140.

[5] Mugehyi, Zhu, C., \& Edmond (2017). Blended learning effectiveness: The relationship between student characteristics, design features and outcomes. International Journal of Educational Technology in Higher Education 14(7), 1-20.

[6] Nalin, S. (2014). A perspective on blended learning approach through course management system: Thailand's case study. International journal of information and education technology, 4(2), 172-175.

[7] Nwoke, B. I., Akukwe, A. C., Uzoma, P. O., \&Nwanjo, C. L. (2014). Improving teacher education through blended learning in nigeria's colleges of education. Journal of Research in Education and Society, 5(3), 37-42.

[8] Poon, J. (2013). Blended learning: An institutional approach for enhancing students' learning experiences. MERLOT Journal of Online Learning and Teaching, 4(2), 271-288.

[9] Singh, H. (2003). Building effective blended learning program. Journal Educational Techology. 43(6), 51-54.

[10] Widodo, \& Widayanti, L. (2013). Peningkatan aktifitas belajar dan hasil belajar siswa dengan metode problem based learning pada siswa kelas VIIA MTs Donomulyo kulon progo tahun pelajaran 2012/2013. Jurnal Fisika Indonesia, 17(49), 32-35. 